УАK 340.1

ББК 67.0

DOI 10.22394/1682-2358-2021-5-13-20

A.L. Bredikhin, Candidate of Sciences (Law), senior lecturer of the History of the State and Law Department, Saint-Petersburg University of the Ministry of Internal Affairs of Russia

E.D. Protsenko, Doctor of Sciences (Law), Professor of the State Law Department, Herzen State Pedagogical University of Russia

\section{OFFICIAL \\ INTERPRETATION \\ OF LAW \\ IN THE RUSSIAN FEDERATION}

Issues of the official interpretation of law are studied. The author points out the need to revise the traditional understanding of the official interpretation of law, since it does not convey the real meaning of this phenomenon in the modern legal system. The authorial definition of the official interpretation of law is given.

Key words and word-combinations: law, interpretation of law, official interpretation, normative properties, interpretation of the Constitution of the Russian Federation.
А.А. Бредихин, кандидат юридческих наук, стариий преподаватель кафедрь истории государства и права Санкт-Петербургского униbepcumema MBД России (email: axel_b@mail.ru)

E.А. Проченко, доктор юридических наук, профессор кафедриг государственного права Российского государственного педагогического университета им. А.И. Гериена (email:arrow54@yandex.ru)

\section{ОФИЦИААЬНОЕ ТОАКОВАНИЕ ПРАВА В РОССИЙСКОЙ ФЕАЕРАЦИИ}

Аннотащия. Исследуются проблемы официального толкования права. Отмечается необходимость пересмотра традиционного понимания официального толкования права, так как оно не передает реальный смысл данного явления в современной правовой системе. Предлагается авторское определение официального толкования права.

Ключевые слова и словосочетания: право, толкование права, официальное толкование, нормативные свойства, толкование Конституции РФ.

$\Pi$ ста) науелено на регулирование обслественных щественных процессов и отношений, непременным условием его реализации явцяется правицьное уяснение норм субъектами правоотношений, правоприменительными органами, гражданами и юридическими миџами. ОАнако 
закон (любой акт законодательства) не всегда может быть правильно понят применительно к конкретной жизненной ситуации мибо смысл нормы права может намеренно искажаться.

Аейственным средством, которое может искиючить неправильное понимание и применение права, является толкование права (правовых норм). В.И. Червонюк определяет толкование права как «особую разновидность соџиального познания, то есть проџесс познания мыслей правотворческого органа, связанный с получением достоверных знаний о содержании норм права» [1, с. 536]. А.П. Рассказов опредемяет, что «толкование норм права (интерпретационная деятельность) - это интелмектуально-волевая деятельность, направленная на определение точного смысла текста правовой нормы и состоящая из двух этапов: уяснения и затем, при необходимости, разъяснения правовой нормы [2, c. 421].

В целом такой подход явмяется общепринятым и не вызывает серьезных научных споров. Ааже на обыденном уровне толкование того или иного понятия выглядит как донесение его истинного смысла до субъекта (конкретного или неограниченного круга Аиџ).

Процесс толкования состоит в основном из двух процессов: уяснения и разъяснения. Аля субъекта, осуществляющего толкование норм права, безусловно, необходимо изначально правицьно понять Аля себя их смысл, а затем приступить к разъяснению.

Следует отметить, что в толковании права определяющее значение имеет цишь официальное толкование. Иные виды толкования, в том числе Аоктринальное, имеют некоторое влияние на реализаџию правовых норм, но актами толкования признаваться не могут. Офиџиальное же толкование нередко подменяет саму норму права, когда она неопределенно регулирует конкретную жкизненную ситуацию и служит среАством устранения пробелов в праве.

Офиџиальное толкование права всегда выражается в акте толкования (точное наименование документа может быть различным), который содержит разъяснение о правильном применении тех или иных норм права. Полагаем, что уяснение как этап толкования права дия официального толкования права не актуален, так как официальные органы, полномочные осуществлять толкование, априори осведомлены об истинном смысле правовой нормы и воле законодателя.

Значение термина «официальное толкование права» не всегда очевидно. Теория государства и права, с одной стороны, однозначно определяет смысл официального толкования, но вынуждена считаться с реальной законодательной и правоприменительной практикой, что не всегда позволяет создать целостную теорию толкования права. 
Под официальным толкованием права буквально следует понимать выраженное в офиџиальном акте толкование, исходящее от законотворческого или иного уполномоченного органа, то есть смысл толкуемой нормы для џелей правоприменения. Следовательно, норму права Аолжен толковать орган, ее издавший цибо имеющий спещиальное полномочие на это.

Примером официального толкования права является толкование Конституции РФ Конституционным Судом РФ, правом на которое он наделен конституционной ст. 125. Такие полномочия имеются также у конституционных (уставных) судов субъектов РФ в части толкования положений конституционных (уставных) актов субъектов РФ, однако это уже мацо актуацьно, так как эти суды прекращают свое существование и новых дел уже не рассматривают. Аругих бесспорных примеров официального толкования норм права привести невозможно, так как ни один из государственных органов законодательством не наделен буквально правом толковать законы (нормы права).

Теоретически толкование норм права от имени государства (а значит, офиџиальное) осушествляется судом (в том числе при применении аналогии закона и права), министерствами и ведомствами (при помощи инструкщий, разъяснений, «нормативных» писем и т.п.), Аругими субъектами в пределах их предметной деятельности. ОАнако подобные акты не называются актами толкования в законе, поэтому и в науке, и в учебном процессе никто не рискнет безапемляџионно назвать такие акты официальным толкованием права.

Вместе с тем, исходя из современной правовой практики правоприменения, целесообразно определить основные виды официального толкования норм права. По мнению авторов учебника по теории государства и права под редакцией А.А. Клишаса, «официальное толкование дается государственными органами или уполномоченными на то государством, которое можно подразделить на аутентическое и демегированное» [3, с. 128]. Такое же по смыслу мнение изложено в учебнике В.В. Аазарева и С.В. Аипеня [4, с. 488].

Аутентичное толкование, по мнению ученых, вытекает из права конкретного государственного органа на издание нормативных правовых актов и не требует специальной фиксации права их толкования. «В подавляющем большинстве случаев такое толкование по своему характеру явмяется нормативным» [4, с. 488]. Из этого можно сделать вывод, что нормы права толкуются с помощью Аругих норм права в рамках реализации полномочий конкретных органов (тех, которые и приняли толкуемую норму). В качестве примера приведем 
ст. 158 УК РФ «Кража», где в примечании толкуются понятия «хищение», «значительный ущерб», «помещение», «хранилище», «крупный размер».

Аелегированное толкование заключается в разъяснении положений нормативного акта, изданного другим правотворческим органом. Право на толкование здесь подтверждается прямым указанием в Аругом нормативном акте мибо вытекает из компетенции конкретного органа власти, то есть если в определенном нормативном акте указано, что конкретный вопрос решается на основании, например, постановления Правительства РФ, то само это постановление будет выступать как акт толкования. Реализацию правотворческих полномочий Правительством РФ, если они принимаются дмя конкретизации законодательных положений, также можно считать актами толкования права.

Таким образом, офищиальное толкование в теории государства и права понимается как законодательная (правотворческая деятельность), связанная с разъяснением (конкретизацией) общих норм, определения объема их правового регулирования (расширительное ици ограничительное толкование). Вместе с тем возникает некоторая путаниџа. Офиџиальное толкование при таком подходе имеется налиџо, а собственно актов толкования не принимается, так как результат толкования выражен в форме нормы права как части нормативного акта.

В противовес теоретическим положкениям об официальном толковании норм права существует государственно-правовая практика, которая фактически устанавливает мибо принимает некоторые акты толкования как официальные, хотя непосредственно правом офиџиального толкования соответствующие органы не наделены. Наука при этом не Аает концептуального ответа о месте таких актов в системе официального толкования. Складывается парадоксальная ситуаџия, когда официального толкования в форме актов толкования не предусмотрено, но существуют акты толкования, исходящие от государственных структур, которые принимаются в качестве таковых законодательством и правоприменительной практикой, но не соответствуют определению, Аанному в правовой науке. Более того, глубокий анализ действующего законодательства вообще ставит под сомнение существование категории «официальное толкование права» в значении, выработанном теорией права, и требует значительных уточнений в понимании этой категории.

Под актом официального толкования права, на наш взгляА, следует понимать исходящий от уполномоченного государством субъекта специальный документ, в котором разъясняется смысл той ици иной 
нормы права, порядок ее применения, а также иные положения, направленные на разъяснение норм права.

Оџенив положения действующего законодательства и российской правоприменительной практики, можкно предложить перечень актов официального толкования права:

1. Постановления Конституционного Суда Российской Федераџии (КС РФ). КС РФ принимает три вида решений: постановления, заключения и определения, но статус актов толкования права может принадлежать именно постановмениям, так как они принимаются по большинству вопросов компетенџии КС РФ. Офиџиальный характер им предает принятие решений «от имени Российской Федерации».

Здесь важно отметить, что непосредственно актами толкования права можно признать два вида постановлений: а) принятые по запросам о толковании Конституции РФ; б) по запросам о разрешении вопросов о возможности исполнения решений межгосударственных органов в их истолковании, противоречащем Конституции РФ. Именно в этих случаях требуется реализация полномочий по «толкованию».

Вместе с тем постановления КС РФ по Аругим вопросам также можно назвать актами официального толкования, так как Амя принятия решения осуществляется оџенка правовых ситуаџий исходя из разъяснения положений Конституџии РФ. Так или иначе, Конституџионный СуА РФ в своих постановлениях занимается толкованием положений Конституции РФ, что явно прослеживается в их мотивировочной части.

Как уже было отмечено, офиџиальный характер толкования, осуществляемого Конституџионным Судом РФ, не оспаривается, однако под определение «официального толкования», Аанного в правовой $\Lambda$ тературе, акты КС РФ не подпадают. Их нельзя отнести ни к аутентичному толкованию, ни к делегированному.

2. Постановления Пленума Верховного Суда РФ. Ао упразднения Высшего Арбитражного суда РФ постановиения Пиенума ВАС РФ имели такой же статус [5, с. 229].

Согласно ст. 2 Федерального конституционного закона от 5 февраля 2014 г. № 3-ФКЗ «О Верховном Суде Российской Федерации», он «в целях обеспечения единообразного применения законодательства Российской Федерации дает судам разъяснения по вопросам судебной практики на основе ее изучения и обобщения». ЗАесь явная игра слов, ибо "разъяснение» это и есть толкование, и, если оно исходит от официального органа судебной власти, то имеется в виду именно офиџиальное толкование.

Если рассматривать не формальную, а практическую сторону, то постановления Пценума ВС РФ не только разъясняют вопросы судеб- 
ной практики, но и дают расширительное или ограничительное толкование тех или иных норм. НереАко, выходя за рамки толкования, высший судебный орган осуществляет фактическое нормотворчество [6, с. 128-129], а в юридической практике правовые позиции, соАержащиеся в постановлениях Пленумов ВС РФ, используются юристами как нормативная основа правовой аргументаџии наряду с правовыми актами.

Кроме того, законодательство в некоторых случаях фактически признает официальное толкование, реализуемое решениями Верховного Суда РФ. Например, Арбитражно-процессуальный кодекс РФ под новыми обстоятельствами, которые служат основанием для пересмотра дела, понимает в том числе определение либо изменение $b$ постановлении Пленума Верховного Суда Российской Федерачии или в постановлении Президиума Верховного Суда Российской Федерачии практики применения правовой нормьг, если в соответствуюшем акте Верховного Суда Российской Федерачии содержится указание на возможность пересмотра вступивиих 8 законную силу судебньхх актов В силу данного обстоятельства. Следовательно, изменение практики применения нормы права (ее толкования по сути) выступает юридически значимым фактом.

Еще больший интерес вызывает то, что в соответствуюшем акте Верховного Суда РФ может быть указана возможкность пересмотра вступивших в силу судебных решений, что уже придает решениям Верховного Суаа РФ в этой части силу нормативного акта.

Кроме того, отметим, что решения судов первой, апемяяионной, кассаџионной и надзорной инстанций также по форме и содержанию представцяют собой акты толкования правовых норм и служат среАством аргументаџии в юридической практике. ОАнако в них толкуется скорее фактическая ситуация, а не норма права, поэтому отнести эти к официальному толкованию нет оснований.

3. Акты, содержащие разъяснения законодательства и обладающих нормативными свойствами (письма Минфина, Минтранса, ФНС, ФАС, ФТС России и Ар.). Появление таких актов связано с анализом и разрешением правовых ситуаций, возникающих в процессе правоприменительной деятельности. В них содержится официальная позиџия государственного органа на преАмет применения правовой нормы к конкретным жизненным обстоятельствам.

Ранее существовала проблема обжалования подобных писем, так как их правовая природа законодательно была не определена и дей-

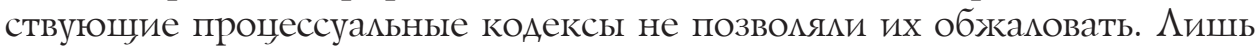
в 2016 г. в Кодексе административного судопроизводства РФ появицась 
ст. 217.1 с названием «Рассмотрение административных дел об оспаривании актов, содержкащих разъяснения законодательства и обладающих нормативными свойствами».

Интересно, что при рассмотрении дел подобной категории, помимо выяснения, нарушает $и$ данный акт права заявителя, суА Аолжен установить, обцадает $и$ оспариваемый акт нормативными свойствами, позволяющими применить его неоднократно в качестве общеобязательного предписания в отношении неопределенного круга Аиц; соответствуют $и$ положения оспариваемого акта действительному смыслу разъясняемых им нормативных положений. Это в совокупности и придает им значение актов офиџиального толкования.

На это же указывают и методические рекомендации, подготовменные в Научном центре правовой информации при Министерстве юстиции Российской Федерации, где опредемяется, что акты, облаАающие нормативными свойствами, по сравнению с нормативными актами «не содержат и не могут содержать новых норм права, в них дается цишь толкование действующего законодательства, то есть разъясняются конкретные законоположкения» [7, с. 8]. 3Аесь также подтверждается, что этим актам придается смысл офиџиального толкования.

Таким образом, выявлены три вида актов официального толкования права, существующих в российской правовой системе. МежАу тем ни Конституционный СуА РФ, ни Верховный СуА РФ не является правотворческим органом, но, даже если их решения все же приобретают статус нормативности, это нарушает всякую могику разделения вцастей.

Что касается так называемых «актов, обладающих нормативными свойствами», то они наиболее точно по форме соответствуют определению актов офиџиального толкования, однако действующее законодательство не придает им юридической силы, равной законоАательству.

На основании изложенного можно сделать следующие выводы.

Во-первых, сложившаяся конщепция официального толкования права не соответствует правовым реалиям, поэтому Аолжна быть скорректирована. Ни аутентичного, ни делегированного толкования действующим законодательством не предусмотрено, не существует его и фактически.

Во-вторых, обозначенные фактически сложившиеся виды официального толкования права позволяют дать определение офиџиального толкования права. Официальное толкование права в Российской ФеАерации - это деятельность высших судебных органов и органов го- 
сударственной власти по разъяснению порядка применения правовых норм к определенным жкизненным ситуациям. Актами официального толкования права явцяются юридически значимые документы, в которых уполномоченные органы излагают результаты толкования правовых норм.

В-третьих, в существующей правовой системе необходимость актов официального толкования не очевидна, так как все нормативные предписания должны быть определены ясно и четко в иерархической структуре правовых актов, и не нуждаться в разъяснениях. Такие разъяснения при необходимости должны облекаться в правовую норму и измагаться в нормативном акте.

Акты офиџиального толкования права расходятся с принџипом законности, так как позвомяют себе отойти от буквального смысла закона и допустить принцип целесообразности. Это указывает на искажение действительной воли законодателя, представляющего интересы народа, явцяющегося единственным источником вцасти.

\section{Библиографический список}

1. Червонюк В.И. Теория государства и права: учебник. М., 2007.

2. Рассказов Л.П. Теория государства и права: углубленный курс: учебник. M., 2015.

3. Теория государства и права: учебник / под ред. А.А. Клишаса. М., 2019.

4. Лазарев В.В. Теория государства и права: учебник для бакалавров. 4-е изд., перераб. и доп. М., 2013.

5. Пастельняк А.В. Проблема толкования нормы права с учетом позиций высших судебных инстанций // Вестник Северо-Кавказского федерального университета. 2013. № 2. C. 227-230.

6. Лепихина Н.В. Толкование норм права в постановлениях Пленума Верховного Суда Российской Федерации // Законность и правопорядок в современном обществе. 2016. № 28.

7. Методические рекомендации по определению нормативности правовых актов субъектов Российской Федерации и муниципальных правовых актов в целях ведения федерального регистра нормативных правовых актов субъектов Российской Федерации, федерального регистра муниципальных нормативных правовых актов и регистров муниципальных нормативных правовых актов субъектов Российской Федерации / Э.И. Атагимова, О.С. Рыбакова. М., 2019. 